\title{
Hubungan Perkembangan Wisata terhadap Ekonomi Wilayah di Gunungkidul Selatan
}

\author{
The Impact of Tourism Development towards Regional Economy at \\ Southern Gunungkidul
}

\author{
Gilang Adinugroho ${ }^{{ }^{*}}$ \\ ${ }^{1}$ Magister Geografi, Fakultas Geografi, Universitas Gadjah Mada, Bulaksumur, Daerah Istimewa Yogyakarta \\ 55281; *Penulis korespondensi, e-mail: gilangadi1878@gmail.com \\ (Diterima: 10 Oktober 2016; Disetujui: 06 Desember 2016)
}

\begin{abstract}
Disparity is still a common problem in regional development, including at Gunung Kidul Regency. Rapid development is taking place at Wonosari, the capital region of Gunungkidul Regency, while other districts are lagged behind, especially the southern part of Gunungkidul which are underdeveloped and having low economic contribution. Tourism is seen as one of the alternatives to increase economic development since the increase of the number of tourists visits. The aims of this study was to identify the tourism sector development in southern Gunungkidul and to analyze its impact towards the district's economy. The method used in this study is quantitative using paired sample t test and Pearson correlation for data analysis. The data showed that there was an increasing trend in the number of tourist visit during 2007 to 2013 eventhough with a lack of tourism infrastructures, especially in Panggang, Saptosari and Girisubo subdistrict. The data also showed that there was an increasing of Gross Regional Domestic Product (GRDP) in trade and entertainment sector between 2007 and 2013. The result of comparative analysis showed that there are significant differences of GRDP of these two sectors between 2007 and 2013. The correlation analysis showed that there was no significant relationship between the number of tourist visits and the extent of the sector in GRDP. High number of visits is not necessarily related to the increasing level of GRDP.
\end{abstract}

Keywords: Southern Gunungkidul, tourism, GRDP, regional economy

\begin{abstract}
ABSTRAK
Permasalahan pembangunan di Kabupaten Gunungkidul adalah ketimpangan pembangunan antar wilayah. Pembangunan hanya berpusat di Wonosari sedangkan lainnya masih tertinggal. Bagian selatan Gunungkidul yang berjumlah enam kecamatan relatif masih tertinggal dan kontribusi ekonominya masih minim. Pariwisata dapat dijadikan alternatif untuk meningkatkan pembangunan ekonomi di bagian selatan karena kunjungan wisatawan ke objek wisata pantai semakin meningkat. Tujuan penelitian ini adalah untuk 1) mengidentifikasi perkembangan sektor pariwisata, dan 2) menganalisis perubahan ekonomi wilayah terkait sektor wisata pantai di selatan Gunungkidul. Metode analisis statistik yang digunakan adalah paired sample t test dan korelasi pearson. Wisatawan yang berkunjung mengalami tren kenaikan dalam periode tahun 2007 sampai 2013. Sarana pendukung wisata masih minim, terutama di Kecamatan Panggang, Saptosari dan Girisubo. Produk Domestik Regional Bruto (PDRB) sektor perdagangan dan sub sektor jasa hiburan di kecamatan bagian selatan Gunungkidul, meningkat drastis dari tahun 2007 ke 2013.
\end{abstract}


Hasil analisis komparasi menunjukkan bahwa ada perbedaan nyata pendapatan nominal kedua sektor tersebut pada tahun 2007 dan 2013. Analisis korelasi menunjukkan bahwa tidak ada hubungan signifikan antara jumlah kunjungan wisata dengan pendapatan sektor. Jumlah kunjungan yang tinggi belum tentu berhubungan dengan tingkat pendapatan sektor.

Kata kunci: Gunungkidul Selatan, wisata, PDRB, komparasi, korelasi

\section{PENDAHULUAN}

Ketimpangan pembangunan di Daerah Istimewa Yogyakarta (DIY) relatif tinggi. Rasio Gini DIY pada September 2016 mencapai 0.42 atau tertinggi kedua setelah Sulawesi Selatan (BPS, 2016). Ketimpangan ini disebabkan oleh terkonsentrasinya kegiatan ekonomi hanya di aglomerasi perkotaan Yogyakarta (Restiatun, 2009). Kabupaten Sleman dan Kota Yogyakarta menyumbang hampir 60\% ekonomi DIY. Ironisnya, luas 2 wilayah tersebut kurang dari $20 \%$ luas DIY. Pusat-pusat pertumbuhan hanya terletak di Kabupaten Sleman dan Kota Yogyakarta sehingga perkembangan ekonominya paling tinggi.

Kabupaten Gunungkidul merupakan daerah yang masih tertinggal pembangunannya di DIY. Luas wilayah Gunungkidul terluas dibandingkan dengan kabupaten/kota lainnya, yaitu $49 \%$ dari luas total DIY. Namun, kontribusi ekonomi kabupaten ini hanya $13.6 \%$ di DIY (BPS, 2014). Indeks Pembangunan Manusia di Gunungkidul juga tertinggal dibandingkan dengan daerah lain dengan tingkat kemiskinan yang cukup tinggi. Ketertinggalan pembangunan di Gunungkidul disebabkan oleh minimnya pusat pertumbuhan, sumber daya alam yang terbatas dan hambatan geografis. Pusat pertumbuhan di Gunungkidul hanya terletak di ibukota kabupaten, yaitu Wonosari (Rahayu, 2014). Karakteristik geografis Gunungkidul adalah lahan marjinal dengan sumberdaya air yang minim (Damayanti, 2008). Hal ini membuat pertanian lahan basah tidak mampu berkembang dengan baik. Kondisi geografis yang berbukit dan bergunung menjadi penghambat kegiatan pembangunan. Indeks Kesulitan Geografis (IKG) Gunungkidul tertinggi dibandingkan dengan kabupaten lainnya yaitu 29.96. Hal tersebut membuat perkembangan Gunungkidul masih rendah dibandingkan daerah lain.

Permasalahan pembangunan di Gunungkidul diperparah oleh ketimpangan antar wilayah (Rahayu, 2014). Kegiatan ekonomi hanya terpusat di bagian tengah dan ibukota kabupaten. Hampir 20\% kontribusi ekonomi disumbang oleh Kecamatan Wonosari (BPS, 2013). Sedangkan 50\% PDRB Gunungkidul disumbangkan oleh 5 kecamatan yaitu Wonosari, Playen, Ponjong, Semanu dan Semin. Tiga belas kecamatan lainnya hanya memiliki kontribusi masing-masing 3 sampai $5 \%$. Wilayah yang masih tertinggal adalah bagian selatan Kabupaten Gunungkidul, yang memiliki karakteristik pegunungan dan pesisir. Kontribusi PDRB wilayah ini hanya 21.09\% terhadap kabupaten. Bagian selatan masih kekurangan sarana prasarana, minim pusat pertumbuhan serta hambatan geografis yang tinggi. Wilayah selatan memerlukan opsi sektor lain untuk meningkatkan perkembangan ekonominya selain sektor pertanian. Pariwisata dapat menjadi leading sector pembangunan di wilayah selatan. Suatu daerah memerlukan sektor yang berperan sebagai export base apabila ingin meningkatkan ekonominya (Tiebout dalam Muta'ali, 2015). Sektor yang berperan sebagai export base memiliki efek pengganda terhadap kegiatan sektor lain.

Sektor pariwisata dapat menjadi sektor alternatif untuk pembangunan di wilayah selatan Gunungkidul (Yuliandi, 2013). Potensi wisata (jasa lingkungan) di wilayah pesisir selatan mencapai 6.8 milyar (Sahubawa et al., 2015). Sektor pariwisata diharapkan memicu ekonomi masyarakat sekitar seperti kegiatan perdagangan atau jasa. Kondisi tersebut didukung semakin meningkatnya jumlah wisatawan yang berkunjung ke objek wisata pantai. Kunjungan wisatawan di pantai pada 
tahun 2011 tidak sampai 600 ribu orang, sedangkan tahun 2015 meningkat hampir lebih dari 300\% menjadi 2 juta orang (Dinas Pariwisata DIY, 2015). Jumlah kunjungan tersebut diharapkan mampu meningkatkan kegiatan ekonomi masyarakat dan wilayah (kecamatan). Data Produk Domestik Regional Bruto (PDRB) menjadi variabel yang dapat mencerminkan kegiatan ekonomi di suatu daerah.

Pariwisata mampu memberikan dampak terhadap kegiatan ekonomi, baik secara mikro, meso atau makro (Suci, 2015; Yoga 2015; Wulandari, 2014; Widodo, 2011). Dampak mikro antara lain peningkatan pendapatan masyarakat atau variasi kegiatan ekonomi bertambah. Peningkatan PAD, pembukaan lapangan pekerjaan merupakan dampak di lingkup meso. Dampak makronya adalah pertumbuhan ekonomi dan PDRB wilayah. Perkembangan kegiatan wisata di selatan Gunungkidul diharapkan mempunyai dampak terhadap ekonomi wilayah.
Dampak wisata dapat bersifat langsung dan tidak langsung (Widyastuti, 2013). Penelitian ini berusaha menganalisis perubahan ekonomi wilayah di selatan Gunungkidul akibat perkembangan sektor pariwisata. Hal ini penting untuk evaluasi, sejauh mana perubahan yang terjadi di tingkat wilayah. Tujuan penelitian adalah sebagai berikut: (1) mengidentifikasi perkembangan kegiatan wisata pantai di selatan Gunungkidul; dan (2) menganalisis perubahan ekonomi wilayah terkait sektor wisata pantai di selatan Gunungkidul.

\section{METODE}

Penelitian ini berlokasi di bagian selatan Kabupaten Gunungkidul. Unit analisis yang digunakan adalah kecamatan. Terdapat 6 kecamatan di bagian selatan yaitu Purwosari, Panggang, Saptosari, Tanjungsari, Tepus dan Girisubo [Gambar 1]. Kecamatan tersebut masing-masing memiliki objek wisata pantai unggulan.

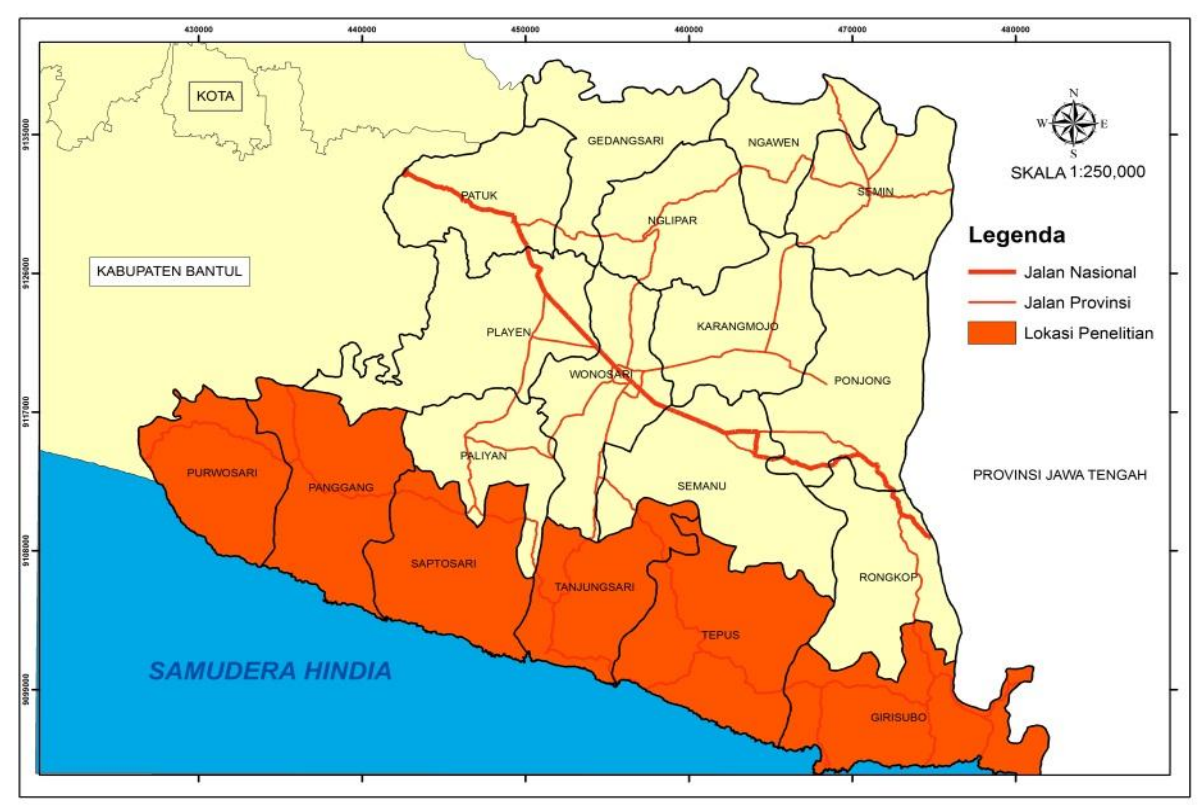

Gambar 1. Lokasi penelitian

Sumber: Hasil pengolahan, 2016.

Metode analisis kuantitatif digunakan dalam penelitian ini. Teknik analisis deskriptif digunakan untuk pembahasan tujuan 1. Teknik analisis yang digunakan untuk tujuan 2 adalah paired sample t test dan korelasi. Teknik paired sample $t$ test digunakan untuk menganalisis perubahan PDRB sebelum dan sesudah booming kegiatan wisata pantai. Sektor yang dianalisis adalah sektor perdagangan, hotel, restoran dan sub-sektor jasa hiburan dan 
rekreasi. Sektor tersebut dapat mencerminkan dampak kegiatan wisata terhadap ekonomi wilayah (Tripomo, 2013). Teknik korelasi mencari hubungan antara jumlah kunjungan wisata tiap kecamatan dengan tingkat pendapatan dua sektor tersebut. Software yang digunakan adalah SPSS 21.

Data yang digunakan adalah data sekunder. Data tersebut adalah PDRB, jumlah pengunjung objek wisata, dan sarana prasarana terkait sektor wisata di tiap kecamatan. Sumber data berasal dari Badan Pusat Statistik dan Dinas Pariwisata, baik DIY maupun Kabupaten Gunungkidul.

\section{HASIL DAN PEMBAHASAN}

\section{Perkembangan Wisata Pantai}

Kabupaten Gunungkidul memiliki garis pantai terpanjang di antara kabupaten lain di DIY. Hal tersebut membuat jumlah objek wisatanya relatif banyak. Jumlah objek wisata terus bertambah dari tahun ke tahun. Jumlah objek wisata pada tahun 2005 hanya 8, sedangkan pada tahun 2015 menjadi 18 objek (BPS, 2015). Hal ini dikarenakan tiap tahun terdapat pembukaan pantai baru.

Tabel 1. Jumlah objek wisata tiap kecamatan

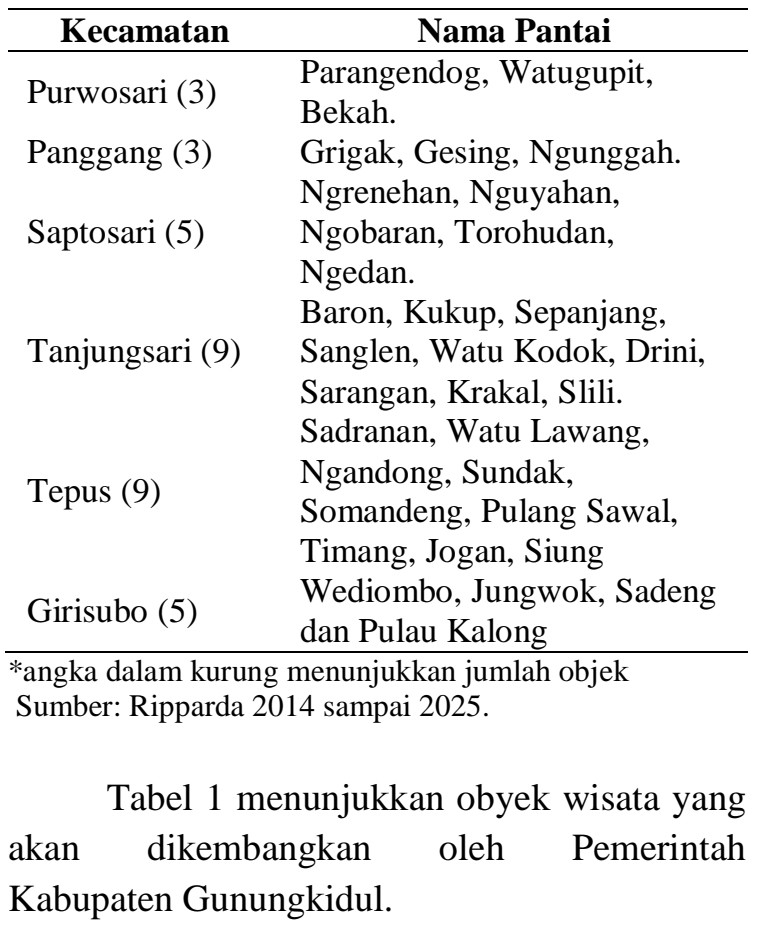

Jumlah pantai yang prioritas akan dikembangkan oleh pemerintah mencapai 32 objek. Jumlah pantai tersebut hanya sebagian dari keseluruhan jumlah objek wisata pantai di kabupaten ini yang berjumlah 60 pantai. Karakteristik pantai di Gunungkidul berbeda dengan pantai di Bantul dan Kulonprogo. Pantai di dua kabupaten tersebut berpasir hitam, sedangkan di Gunungkidul berpasir putih. Hal ini disebabkan oleh perbedaan asal material yang menyusun pantai. Pasir hitam berasal dari material merapi yang dibawa oleh aliran sungai dan diendapkan oleh gelombang pantai selatan (Khakhim, 2008). Pasir putih berasal dari pecahan karang akibat hantaman gelombang dan ombak (Khakhim, 2008). Sebagian orang menganggap bahwa pantai berpasir putih mempunyai daya tarik lebih besar.

Keunikan pantai di Gunungkidul yang lain adalah karakteristik objek yang beragam, baik dari segi fisik dan atraksi. Perbedaan fisik disebabkan oleh proses geomorfologi yang berbeda pula di setiap pantai. Terdapat tiga tipe yaitu structurally shaped coast (pesisir yang terbentuk dari proses patahan/lipatan), wave erosion coast (pesisir yang terbentuk dari proses aktivitas gelombang), dan marine deposition coast (pesisir yang terbentuk dari proses pengendapan material sedimen) (Marfai, 2013). Structurally shape coast merupakan pantai yang terdiri atas tebing-tebing curam. Wave erosion coast merupakan pantai yang terdapat beberapa kenampakan seperti teras marin, pelataran pantai atau pulau yang terpisah. Tipe terakhir adalah marine deposition coast yaitu teluk atau gisik saku di wilayah pantai. Perbedaan kondisi fisik menawarkan pemandangan yang berbeda pula kepada wisatawan. Atraksi yang ditawarkan di objek wisata pantai Gunungkidul juga beragam. Wisata kuliner hasil tangkapan nelayan dapat dinikmati di beberapa pantai seperti Baron, Ngrenehan dan Siung. Kegiatan camping bisa dilakukan di Pantai Jungwok, Ngedan atau Puncak Kosakora di Pantai Drini. Kegiatan snorkeling terdapat di Pantai Nglambor. Keragaman tipologi dan atraksi pantai di Gunungkidul dapat mengundang wisatawan 
yang lebih banyak. Gambar 2 menunjukkan keragaman kondisi fisik dan atraksi wisata di Gunungkidul.

Kunjungan wisata pantai di Gunungkidul pada tahun 2013 mencapai 1,822,251 wisatawan (Dinas Pariwisata DIY, 2014). Jumlah tersebut meningkat $42 \%$ dari kunjungan pada tahun 2012. Wisata pantai di Gunungkidul mempunyai peran strategis dalam sektor pariwisata. Kunjungan objek wisata pantai berkontribusi $81 \%$ jumlah wisatawan yang berkunjung di kabupaten ini. Semua wisatawan yang berkunjung di pantai selatan adalah wisatawan berasal dari dalam negeri. Wisatawan mancanegara lebih banyak mengunjungi objek desa wisata. Ketertarikan terhadap atraksi budaya dan kehidupan perdesaan menjadi faktor utama.

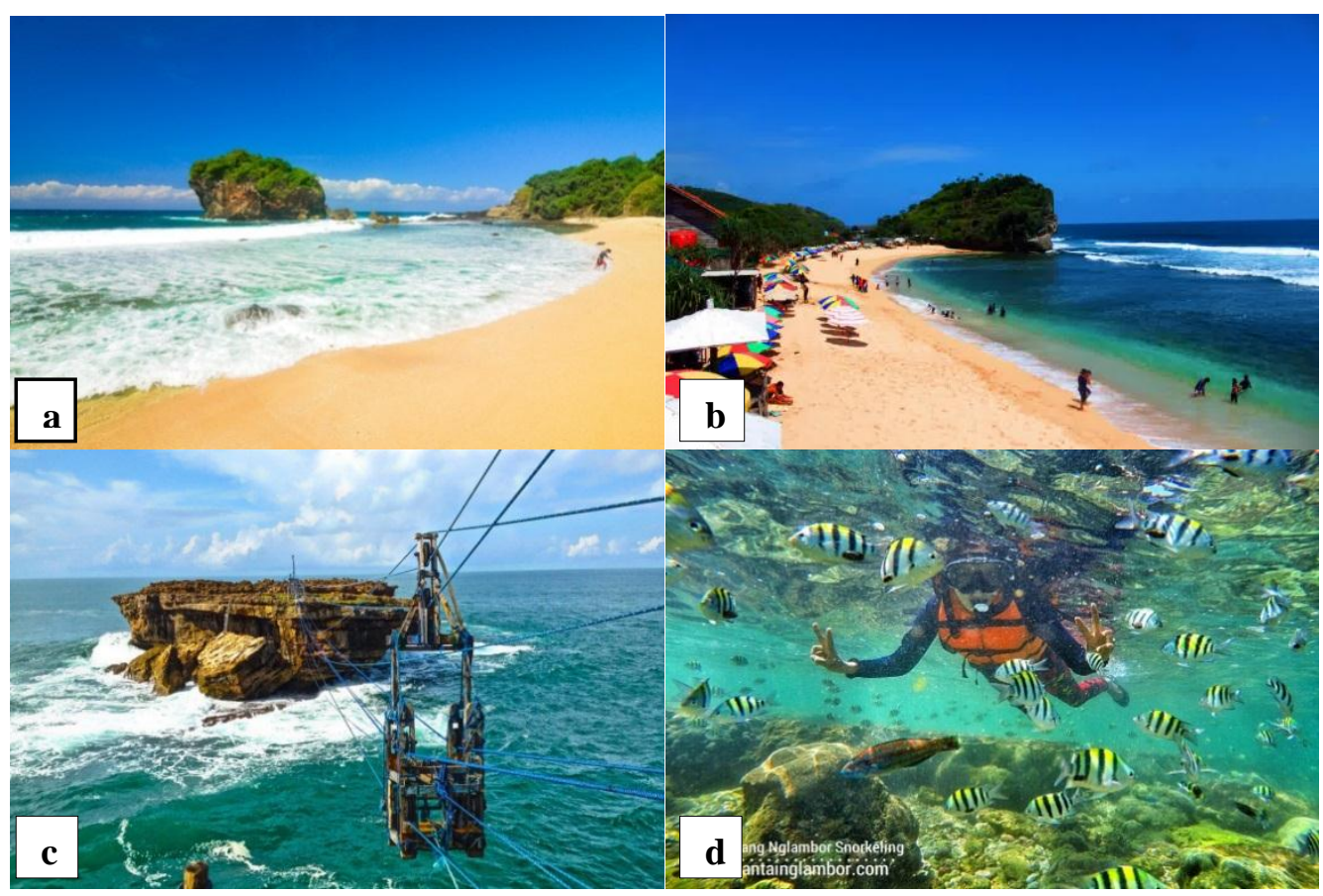

Gambar 2. a) Pantai Jungwok, b) Indrayanti, c) Timang, d) Nglambor Sumber: wisataku.net, piknikdong.com, spotunik.com, pantainglambor.com

Kecamatan Tanjungsari memiliki jumlah kunjungan terbanyak diantara kecamatan di bagian selatan Gunungkidul yaitu sebesar 793,865 orang (BPS, 2014). Kecamatan Purwosari hanya dikunjungi 3,000 wisatawan orang pada tahun 2013. Objek wisata di Tanjungsari relatif sudah dikenal masyarakat dibandingkan dengan objek di kecamatan lain. Pantai Baron, Kukup atau Drini sudah menjadi objek wisata sejak tahun 1990-an. Hal ini membuat objek tersebut menjadi favorit bagi wisatawan. Sarana prasarana yang lengkap dan akses yang mudah, menjadi alasan lain Tanjungsari paling banyak dikunjungi oleh wisatawan. Jumlah objek wisata yang mencapai belasan pantai juga menjadi alasan lain mengapa kecamatan ini menjadi destinasi favorit.
Kunjungan wisata di Kecamatan Purwosari, Girisubo Saptosari, dan Panggang relatif masih rendah. Beberapa objek wisata di kecamatan tersebut masih dikembangkan sehingga belum banyak dikenal oleh masyarakat. Jarak yang relatif jauh dari Wonosari dan minimnya sarana prasarana dimungkinkan menjadi alasan masih sedikitnya wisatawan yang berkunjung. Beberapa pantai di wilayah tersebut juga harus ditempuh melalui jalan kaki atau jalan dengan kondisi yang kurang baik. Hal tersebut dapat menurunkan minat wisatawan untuk berkunjung. 
Tabel 2. Jumlah wisatawan tahun 2007 dan 2013

\begin{tabular}{|c|c|c|}
\hline \multirow{2}{*}{ Kecamatan } & \multicolumn{2}{|c|}{ Kunjungan (orang) } \\
\hline & 2007 & 2013 \\
\hline Purwosari & 0 & 3,000 \\
\hline Panggang & 0 & 0 \\
\hline Saptosari & 12,710 & 41,268 \\
\hline Tanjungsari & 245,648 & 793,865 \\
\hline Tepus & 26,705 & 431,302 \\
\hline Girisubo & 24,599 & 69,631 \\
\hline
\end{tabular}

Sumber: Gunungkidul dalam Angka.

Tabel 2 menunjukkan perkembangan jumlah wisatawan di objek wisata pantai di Gunungkidul.

Perkembangan jumlah wisatawan dari tahun 2007 sampai dengan 2013 relatif pesat. Hampir semua mengalami kenaikan lebih dari 200\%. Kecamatan Purwosari pada tahun 2007 belum dikunjungi wisatawan karena objek wisatanya belum dibuka. Kecamatan Panggang belum dikunjungi wisatawan karena belum ada objek wisata yang dikembangkan. Rencana pengembangan dari pemda diharapkan dapat memunculkan dan meningkatkan kunjungan wisatawan di Purwosari dan Panggang. Jumlah wisatawan yang semakin banyak diharapkan dapat berdampak terhadap ekonomi masyarakat dan wilayah

Pengembangan wisata memerlukan sarana dan prasarana yang memadai. Hal ini memberikan kenyamanan wisatawan untuk beraktivitas di lokasi obyek wisata. Sarana dan prasarana juga diperlukan untuk meningkatkan dampak ekonomi dari kegiatan wisata. Semakin lengkap fasilitas maka wisatawan akan membelanjakan uangnya lebih banyak dan ratarata lama tinggal semakin lama. Pengeluaran yang dilakukan wisatawan tersebut yang akan menggerakkan ekonomi masyarakat dan wilayah (Yoga, 2015; Amir, 2015). Fasilitas yang dibutuhkan antara lain warung, restoran, toko souvenir, hotel, penginapan dan jasa pendukung lainnya. Ketersediaan jaringan transportasi dan komunikasi juga penting untuk memudahkan perjalanan dan interaksi bagi wisatawan.
Tabel 3. Jumlah fasilitas tahun 2015

\begin{tabular}{lrc}
\hline \multicolumn{1}{c}{ Kecamatan } & Hotel & $\begin{array}{c}\text { Restoran/ } \\
\text { Rumah Makan }\end{array}$ \\
\hline Purwosari & 27 & 23 \\
Panggang & 0 & 6 \\
Saptosari & 0 & 2 \\
Tanjungsari & 8 & 163 \\
Tepus & 21 & 167 \\
Girisubo & 0 & 8 \\
\hline Sumber: 1) Gunungkidul dalam Angka 2016. \\
2) Direktori Hotel dan Akomodasi 2015.
\end{tabular}

Tabel 3 menunjukkan jumlah fasilitas pendukung di bagian selatan Gunungkidul tahun 2015.

Hotel yang ada di kawasan selatan Gunungkidul berjumlah 56 tempat. Terdiri atas 1 hotel berbintang dan 55 non-bintang (melati/penginapan). Fasilitas hotel terdapat di tiga kecamatan yaitu Purwosari, Tanjungsari, dan Tepus. Kecamatan Purwosari memiliki hotel paling banyak yaitu 27, sedangkan Tanjungsari delapan tempat dan Tepus 21 tempat. Hotel di Purwosari lebih menyasar wisatawan yang berkunjung ke Parangtritis dibandingkan dengan wisatawan pantai Gunungkidul. Hal ini karena lokasi Purwosari yang berbatasan langsung dengan Kawasan Parangtritis-Depok di Bantul. Jumlah restoran atau rumah makan mencapai 369 unit. Lebih dari setengah restoran/rumah makan terletak di Tanjungsari dan Tepus. Jumlah di kecamatan lain bahkan tidak mencapai 30 unit.

Keberadaan fasilitas akan mengikuti wilayah yang paling berkembang. Kecamatan Tanjungsari dan Tepus merupakan wilayah yang paling berkembang kegiatan wisatanya di bagian selatan. Setiap tahun dua kecamatan tersebut dikunjungi 400 ribu sampai 1 juta wisatawan. Hal ini menjadi daya tarik bagi pengusaha untuk mendirikan hotel dan restoran. Sarana transportasi dan komunikasi yang relatif lengkap dimungkinkan juga menjadi faktor yang berpengaruh. Fasilitas pendukung di Purwosari, Panggang, Saptosari dan Girisubo masih minim. Kondisi ini karena belum berkembangnya wisata di empat kecamatan tersebut. Wisatawan yang datang berkunjung masih dibawah 100 ribu tiap tahunnya. Jumlah yang masih sedikit mengurangi minat 
pengusaha atau masyarakat untuk membangun restoran atau hotel.

Sarana perbankan seperti bank atau ATM belum terdapat di objek wisata pantai. Bank hanya berlokasi di ibukota kecamatan yang berjarak lebih dari lima kilometer dari pantai. ATM masih relatif minim, terdekat hanya di Kecamatan Playen yang berjarak belasan kilometer dari objek wisata. Threshold di objek wisata relatif rendah sehingga dianggap belum memerlukan pembangunan ATM atau bank. Terdapat beberapa minimarket di wilayah selatan Gunungkidul, yang biasanya berlokasi di ibukota kecamatan. Hal ini akan memudahkan wisatawan yang akan berbelanja terutama produk kebutuhan sehari-hari. Sarana komunikasi harus diperbaiki karena beberapa lokasi masih minim, bahkan tidak ada sinyal. Sinyal di Pantai Baron, Krakal atau Drini relatif sudah baik akan tetapi di Ngrenehan, Ngobaran dan Nguyahan sangat minim. Kondisi ini harus menjadi perhatian karena kelancaran komunikasi menjadi aspek penting.

\section{Perubahan Ekonomi Wilayah}

Kegiatan pariwisata dapat berdampak terhadap ekonomi masyarakat dan wilayah (Anisiewicz, 2014; Studizienski, 2015). Pembahasan bagian ini akan mengidentifikasi ada atau tidaknya perubahan terhadap ekonomi wilayah setelah kegiatan wisata berkembang. Pembahasan lainnya adalah hubungan antara jumlah kunjungan wisata dengan tingkat pendapatan sektor perdagangan dan sub sektor jasa rekreasi. Variabel ekonomi wilayah yang digunakan adalah PDRB tiap kecamatan. Sektor PDRB yang dibahas adalah sektor perdagangan, hotel, dan restoran dan sub sektor jasa hiburan. Kedua sektor tersebut dapat menggambarkan kontribusi kegiatan wisata dalam ekonomi wilayah.
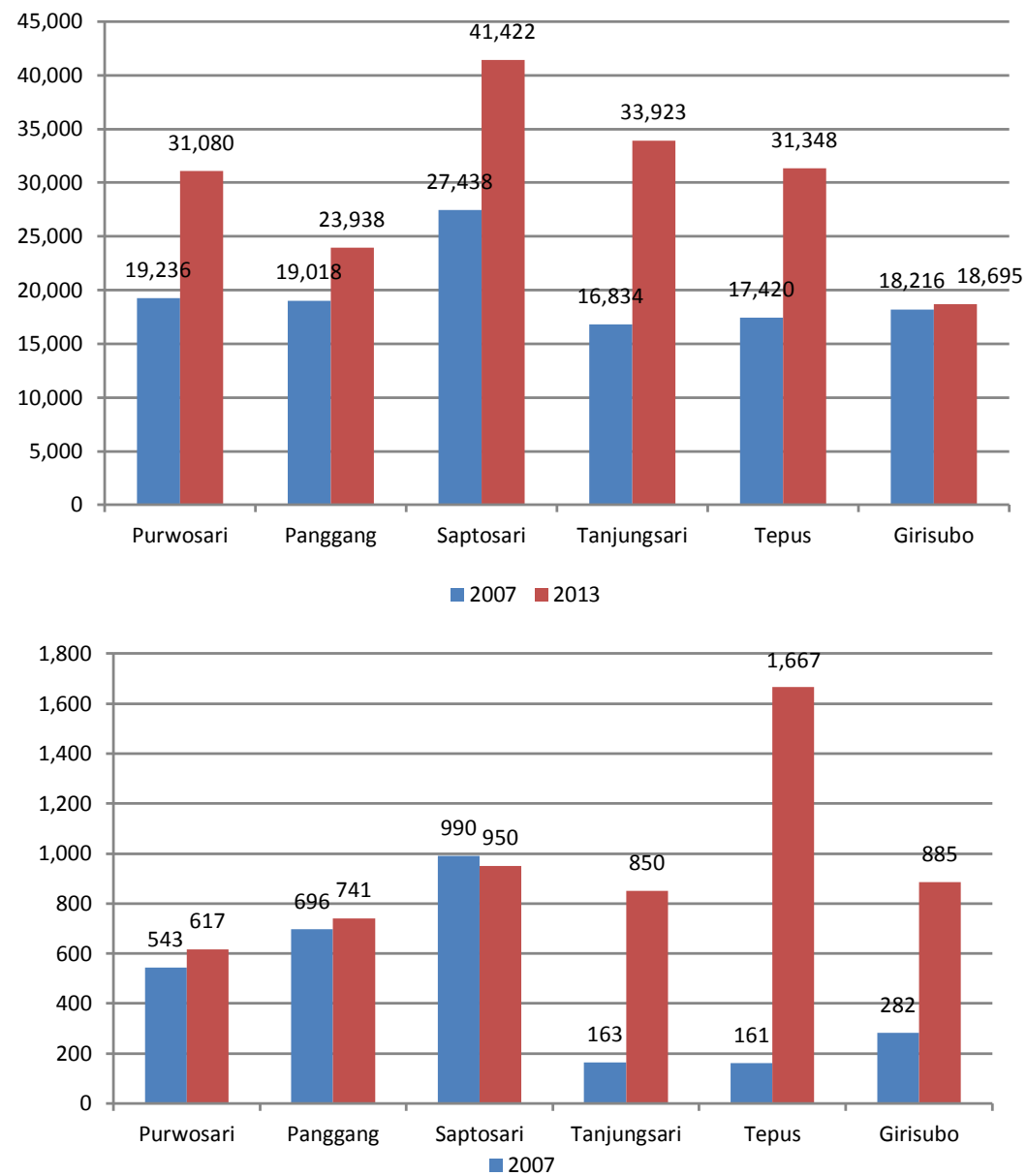

Gambar 3. Pendapatan sektor perdagangan dan sub sektor jasa hiburan tahun 2007 dan 2013 Sumber: BPS dan hasil pengolahan, 2016. 
Gambar 3 menunjukkan pendapatan dua sektor tersebut pada tahun 2007 dan 2013.

Pendapatan sektor perdagangan di selatan Gunungkidul menurut harga berlaku pada tahun 2007 mencapai 118.16 milyar sedangkan tahun 2013 meningkat menjadi 180.41 milyar. Sub sektor jasa rekreasi juga mengalami kenaikan pendapatan selama tahun 2007 sampai 2013. Pendapatan pada 2007 mencapai 2.8 milyar sedangkan tahun 2013 menjadi 5.7 milyar. Hal yang harus menjadi perhatian adalah menurunnya kontribusi dua sektor tersebut di bagian selatan dalam lingkup kabupaten. Kontribusi terhadap kabupaten pada tahun 2007 mencapai $27.53 \%$ dan $46.77 \%$, sedangkan tahun 2013 menurun menjadi 13 dan $28 \%$. Kondisi ini menunjukkan bahwa kegiatan dua sektor tersebut di kecamatan selain di bagian selatan berkembang lebih pesat. Hal ini menunjukkan perkembangan dua sektor tersebut di bagian selatan relatif lebih lambat sehingga kontribusinya terhadap kabupaten semakin menurun.

Pertumbuhan pendapatan sektor perdagangan paling tinggi yaitu di Kecamatan Tanjungsari yaitu 52.09\%. Kecamatan Tepus mengalami peningkatan terbesar di sub-sektor jasa rekreasi dan hiburan yaitu $305 \%$ selama 2007 sampai 2013. Hal ini tidak mengherankan karena dua kecamatan tersebut memiliki pengunjung wisatawan tertinggi dibandingkan dengan kecamatan lain di bagian selatan
Gunungkidul. Kecamatan Purwosari juga mengalami kenaikan relatif tinggi di sektor perdagangan, hotel dan restoran selama 2007 sampai 2013. Penambahan jumlah hotel yang berada di kecamatan tersebut dimungkinkan menjadi faktor peningkatan pendapatan. Jumlah wisatawan yang relatif tinggi dimungkinkan mempunyai dampak terhadap kegiatan di dua sektor tersebut. Pemerintah diharapkan meningkatkan pengembangan wisata selain di Tepus dan Tanjungsari sehingga keuntungan ekonomi dapat dirasakan oleh semua kecamatan di bagian selatan.

Pembahasan selanjutnya adalah perbedaan pendapatan sektor perdagangan dan jasa rekreasi hiburan pada tahun 2007 dan 2013. Hal ini untuk mengidentifikasi apakah ada perbedaan tingkat pendapatan sehingga mencerminkan adanya perkembangan. Teknik analisis yang digunakan adalah uji beda paired sample $t$ test. Teknik ini digunakan karena dua alasan yaitu: (1) jenis data pendapatan PDRB adalah rasio, dan (2) data 6 kecamatan di selatan Gunungkidul) diukur dua kali, pada tahun 2007 dan 2013.

Langkah pertama adalah mengidentifikasi distribusi normal dari data. Salah satu syarat dalam dalam statitistik parametris adalah data harus berdistribusi normal.

Tabel 4. Analisis distribusi normal dengan Kolmogorov-Smirnov (KS)

\begin{tabular}{llrrrr}
\hline & \multicolumn{2}{c}{ One-Sample Kolmogorov-Smirnov Test } & & \\
\hline & & Dagang07 & Dagang13 & Jasa07 & Jasa13 \\
\hline N & & 6 & 6 & 6 & 6 \\
Normal Parameters ${ }^{\text {a,b }}$ & Mean & 10777.00 & 13031.00 & 422.33 & 677.67 \\
& Std. Deviation & 3008.998 & 2716.251 & 155.091 & 162.816 \\
& Absolute & .216 & .185 & .189 & .282 \\
Most Extreme Differences & Positive & .216 & .131 & .180 & .282 \\
& Negative & -.140 & -.185 & -.189 & -.216 \\
Kolmogorov-Smirnov Z & & .529 & .452 & .463 & .690 \\
Asymp. Sig. (2-tailed) & & .942 & .987 & .983 & .727 \\
\hline a. Test distribution is Normal. & & & & &
\end{tabular}

Tabel 4 menunjukkan analisis distribusi normal dengan Kolmogorov-Smirnov (KS). Hasil analisis KS menunjukkan bahwa nilai signifikansi data perdagangan 2007 sebesar 0.942; perdagangan 2013 (0.987), jasa rekreasi 2007 (0.983) dan jasa rekreasi tahun 2013 
sebesar (0.727). Nilai tersebut di atas 0.05 sehingga datanya berdistribusi normal. Distribusi suatu data dianggap normal apabila nilai signifikansi lebih besar dari 0.05 apabila kurang dari 0.05 maka datanya tidak berdistribusi normal. Hasil tersebut menunjukkan bahwa analisis paired sample $t$ test dapat dilanjutkan.
Rata-rata pendapatan sektor perdagangan, hotel dan restoran tahun 2007 mencapai 10.7 milyar, sedangkan tahun 2013 sebesar 12.03 milyar. Pendapatan jasa rekreasi memiliki rata-rata 422 juta pada 2007 dan 677 juta pada 2013. Hasil analisis menunjukkan bahwa nilai t sektor perdagangan tahun 2007 dan 2013 sebesar -2.481, sedangkan jasa 2007 dan 2013 sebesar -2.839 [Tabel 5].

Tabel 5. Paired sample t test

\begin{tabular}{lrrrrr}
\hline & Mean & Std. Deviation & \multicolumn{1}{c}{ t } & df & \multicolumn{1}{c}{ Sig. (2-tailed) } \\
\hline Dagang07 - Dagang 13 & -2254 & 2225.393 & -2.481 & 5 & .056 \\
Jasa07 - Jasa13 & -255 & 220.286 & -2.839 & 5 & .036 \\
\hline
\end{tabular}

Sumber: Hasil Pengolahan SPSS, 2016.

Nilai signifikansi tersebut lebih besar dari 0.05 sehingga menunjukkan adanya perbedaan pendapatan yang nyata pada dua sektor tersebut pada tahun 2007 dan 2013. Hal ini menggambarkan perubahan pendapatan sektor perdagangan dan sub sektor jasa rekreasi di bagian selatan Gunungkidul. Sektor pariwisata dimungkinkan dapat menjadi sektor alternatif untuk peningkatan ekonomi wilayah. Kunjungan wisatawan diharapkan mampu meningkatkan ekonomi wilayah terutama pada sektor tersebut. Analisis statistik korelasi dapat mengungkap hubungan antara jumlah kunjungan wisatawan dengan tingkat pendapatan. Jenis korelasi yang digunakan adalah pearson product moment karena jenis data (jumlah kunjungan dan pendapatan) yang digunakan adalah interval dan rasio. Langkah pertama adalah mengukur ke"normal"an data yang akan dibahas, terutama data kunjungan wisatawan [Tabel 6].

Tabel 6. One-Sample Kolmogorov-Smirnov Test

\begin{tabular}{llr}
\hline & & Kunjungan \\
\hline $\mathrm{N}$ & & 6 \\
Normal Parameters & Mean & 223177.67 \\
& Std. Deviation & 323714.057 \\
& Absolute & .349 \\
Most Extreme Differences & Positive & .349 \\
& Negative & -.245 \\
Kolmogorov-Smirnov Z & & .855 \\
Asymp. Sig. (2-tailed) & & .458 \\
\hline a. Test distribution is Normal. & & \\
b. Calculated from data. &
\end{tabular}

Tabel 7. Correlations

\begin{tabular}{llr}
\hline & & Kunjungan \\
\hline \multirow{5}{*}{ Dagang13 } & Pearson Correlation & .652 \\
& Sig. (2-tailed) & .161 \\
& $\mathrm{~N}$ & 6 \\
Jasa13 & Pearson Correlation & -.066 \\
& Sig. (2-tailed) & .901 \\
& $\mathrm{~N}$ & 6 \\
Kunjungan & Pearson Correlation & 1 \\
& Sig. (2-tailed) & 6 \\
\hline
\end{tabular}


Nilai Asymp sig data kunjungan sebesar 0.458 atau lebih dari 0.05 . Hal ini menunjukkan bahwa data kunjungan wisatawan di enam kecamatan tersebut terdistribusi normal sehingga dapat digunakan untuk langkah selanjutnya.

Hasil analisis korelasi pearson product moment terdapat dalam Tabel 7. Langkah pertama dalam korelasi adalah mengidentifikasi nilai signifikansi antar hubungan. Nilai hubungan kunjungan-jasa (0.901) dan kunjungan-perdagangan (0.161). Semua hubungan mempunyai nilai signifikansi lebih dari 0.05 , yang menunjukkan tidak ada hubungan yang signifikan dalam tiga korelasi tersebut. Dengan kata lain bahwa kecamatan yang memiliki kunjungan wisata yang tinggi belum tentu pendapatan dua sektor tersebut juga tinggi. Kecamatan Saptosari yang kunjungan wisatawannya lebih sedikit dibandingkan dengan Tepus dan Tanjungsari, justru memiliki pendapatan sektor perdagangan yang lebih tinggi. Pembangunan Jalan Lintas Selatan (JLS) dimungkinkan menjadi penyebab meningkatnya pendapatan sektor perdagangan di selatan Gunungkidul. Pembangunan tersebut kemungkinan berdampak terhadap kemudahan akses sehingga terjadinya peningkatan arus kendaraan. Hal ini akan memicu kegiatan ekonomi di daerah yang dilewati JLS. Beberapa toko dan warung bermunculan di sekitar JLS, bahkan terdapat toko berjejaring nasional. Kondisi tersebut akan berdampak terhadap pendapatan dari sektor perdagangan. Hasil penelitian ini berbanding terbalik dengan beberapa penelitian terkait. Kenaikan jumlah pengunjung ternyata berpengaruh siginfikan terhadap pendapatan ekonomi wilayah (Othman, 2012; Jin, 2011; dan Tang, 2013). Hal ini dapat menjadi bahan penelitian selanjutnya terkait dampak kegiatan wisata terhadap ekonomi makro di Gunungkidul.

Penelitian terkait tingkat belanja masyarakat di objek wisata dapat mendukung hasil analisis korelasi. Jumlah kunjungan yang tinggi belum tentu berdampak terhadap ekonomi wilayah apabila tingkat belanja wisatawan relatif rendah. Data PDRB juga mempunyai kelemahan karena lingkup kegiatannya kecamatan sedangkan objek wisata hanya di beberapa lokasi. Penelitian selanjutnya dapat menggunakan indikator atau data yang detail sehingga dapat menggambarkan dampak sektor pariwisata terhadap pembangunan.

\section{KESIMPULAN DAN KEBIJAKAN}

\section{Kesimpulan}

Kesimpulan yang dapat diambil dalam penelitian ini adalah:

Jumlah objek wisata pantai di bagian selatan Gunungkidul semakin bertambah setiap tahunnya. Wisatawan yang berkunjung mengalami tren kenaikan dalam periode 2007 sampai 2013. Hampir semua kecamatan di bagian selatan mengalami peningkatan jumlah kunjungan secara drastis dalam periode 2007 sampai 2013, ketika $80 \%$ wisatawan berkunjung ke Kecamatan Tanjungsari dan Tepus. Ketersediaan sarana pendukung wisata hanya terdapat di sebagian kecamatan. Hotel hanya berada di Purwosari, Tanjungsari dan Tepus serta jumlah restoran paling banyak di Tanjungsari dan Tepus. Fasilitas pendukung lainnya seperti sinyal masih minim, kecuali di pantai yang sudah berkembang.

Pendapatan sektor perdagangan dan sub sektor jasa hiburan di kecamatan bagian selatan Gunungkidul meningkat drastis. Peningkatan pendapatan paling tinggi berada di Kecamatan Tanjungsari dan Tepus. Hasil analisis komparasi menunjukkan bahwa ada perbedaan nyata pendapatan dua sektor tersebut antara tahun 2007 dengan 2013. Hal tersebut menunjukkan adanya perubahan pendapatan sektor perdagangan dan jasa hiburan di bagian selatan Gunungkidul. Analisis korelasi menunjukkan bahwa tidak ada hubungan signifikan antara jumlah kunjungan wisata dengan pendapatan perdagangan dan jasa hiburan. Jumlah kunjungan yang tinggi belum tentu tingkat pendapatan dua sektor tersebut juga tinggi. 


\section{Kebijakan}

Pendapatan perdagangan dan jasa hiburan wilayah mengalami perubahan sejak jumlah wisatawan di objek wisata pantai berkembang. Hal yang harus menjadi perhatian bahwa sebagian besar wisatawan berkunjung di dua kecamatan yaitu Tanjungsari dan Tepus. Pemerintah Kabupaten Gunungkidul diharapkan mengembangkan objek wisata pantai di empat kecamatan lainnya karena kunjungannya masih sedikit. Kondisi objek wisata pantai selain Tanjungsari dan Tepus masih belum berkembang. Sarana prasarana minim dan belum banyak masyarakat yang mengetahuinya. Pengembangan di empat kecamatan lainnya diharapkan akan meningkatkan dan memeratakan tingkat kunjungan wisatawan. Hal tersebut perlu dilakukan agar keuntungan ekonomi dari wisata pantai tidak hanya di Tanjungsari dan Tepus tetapi juga di kecamatan lain di bagian selatan Gunungkidul. Dampak sektor pariwisata tidak hanya di sektor ekonomi akan tetapi sektor lain seperti sumberdaya manusia, tenaga kerja dan kebudayaan masyarakat (Waluya, 2013).

\section{DAFTAR PUSTAKA}

Amir, S., Osman, M. M., Bachok, S., \& Ibrahim, M. (2015). Local Economic Benefit in Shopping and Transportation: A study on tourists' expenditure in Melaka, Malaysia. Procedia Social and Behavioral Sciences, 222, 374381.

Anisiewicz, R., \& Palmowski, T. (2014). Small Border Traffic and Cross-border Tourism Between Poland and The Kaliningrad Oblast of The Russian Federation. Quaestiones Geographicae, 3 (2), 79-85.

Badan Pusat Statistik. (2016). Laporan Bulanan Data Sosial Ekonomi Edisi September 2016. BPS.

Badan Pusat Statistik Kabupaten Gunungkidul. (2013) Produk Domestik Regional Bruto Kecamatan di Kabupaten Gunungkidul 2013. BPS Kabupaten Gunungkidul.

Badan Pusat Statistik Kabupaten Gunungkidul. (2015). Gunungkidul dalam Angka 2014. BPS Kabupaten Gunungkidul.
Damayanti, A., \& Ayuningtyas, R. (2008). Karakteristik Fisik dan Pemanfaatan Pantai Karst Kabupaten Gunungkidul. Makara Teknologi, 12 (2), 91-98.

Dinas Pariwisata DIY. Statistik Kepariwisataan (2014). Dinas Pariwisata DIY.

Jin, C. J. (2011). The Effects of Tourism on Economic Growth in Hong Kong. Cornell Hospitality Quarterly, 2 (3).

Khakim, N., Soedharma, D., Mardiastuti, A., Siregar, V.P., \& Boer, M. (2008). Analisis Preferensi Visual Lanskap Pesisir DIY untuk Pengembangan Pariwisata Pesisir menuju Pada Pengelolaan Wilayah Pesisir Berkelanjutan. Forum Geografi, 22 (1), 4459.

Marfai, M. A., Cahyadi, A., \& Anggraini, F.D. (2013). Tipologi Dinamika dan Potensi Bencana di Pesisir Kawasan Karst Kabupaten Gunungkidul, Forum Geografi, 27 (2), 151162.

Muta'ali, L. (2015). Pengembangan Kawasan Strategis Ekonomi. BPFG UGM.

Othman, R., Salleh, N.H.M., \& Sarmidi, T. (2012). Analysis of causal relationship between tourism development, economic growth and foreign direct investment. Journal of Applied Science, 12 (2), 1245-1254.

Rahayu, E., \& Santoso, E. B. (2014).Penentuan Pusat-Pusat Pertumbuhan Dalam Pengembangan Wilayah di Kabupaten Gunungkidul, Jurnal Teknik Pomits, 3 (2), $290-295$.

Restiatun. (2009). Identifikasi Sektor Unggulan Dan Ketimpangan Antar Kabupaten/Kota di Provinsi DIY. Jurnal Ekonomi dan Studi Pembangunan, 10 (1), 77-98.

Sahubawa, L., Khakim, N., \& Lasindrang, M. (2015). Kajian Sebaran Potensi Ekonomi Sumberdaya Kelautan di Pantai Selatan DIY sebagai Upaya Percepatan Investasi. Jurnal Teknosains, 4 (22).

Studzieniecki, T., Palmowski, T., \& Korneevets, V. (2015). The System of cross-border tourism in the Polish-Russian Borderland. Procedia Economics and Finance, 39, 545-552.

Suci, A. R., \& Pahlawan, I. (2015) Dampak Tour De Singkarak Terhadap Ekonomi Pariwisata di Indonesia (Studi Kasus Provinsi Sumatera Barat). JOM FISIP, 2 (2) 
Tang, C. F. (2013). Temporal Granger causality and the dynamics relationship between real tourism receipts, real income, real exchanger rates in Malaysia. International Journal of Tourism Research, 15 (3), 272-284.

Tripomo, R. S., \& Soesatyo, Y. (2014). Pengaruh Jumlah Wisatawan Objek Wisata Gunung Bromo terhadap sektor Perdagangan, Hotel dan Restoran di Kabupaten Probolinggo. Jurnal Pendidikan Ekonomi, 2 (3).

Waluya, J. (2013). Dampak Pengembangan Pariwisata. REGION, 5 (1).

Widodo, Y., Fandeli, C., Baiquni, M., \& Damanik, J. (2011). Dampak Pariwisata Waduk Kedung Ombo (WKO) terhadap Kesejahteraan Masyarakat Lokal. Jurnal Widyatama, 11 (2).

Widyastuti, N, K. (2013). Pengaruh Sektor Pariwisata Terhadap Kinerja Keuangan Daerah dan Kesejahteraan Masyarakat Kabupaten/Kota di Provinsi Bali. Jurnal Ekonomi dan Bisnis, 2 (5), 292-311

Wulandari, W. (2014). Dampak Kebijakan Perizinan Investasi Bidang Pariwisata (Objek dan Daya Tarik Wisata) Terhadap Perekonomian Kota Wisata Batu Tahun 2010-2013. Jurnal Ilmiah Mahasiswa FEB, 3 (1).

Yoga, I Gde A. D., \& Wenagama, I. W. (2015). Pengaruh Jumlah Kunjungan dan Pengeluaran Wisatawan Mancanegara Terhadap PDRB Provinsi Bali Tahun 19962012. Jurnal Ekonomi Pembangunan, 4 (2).

Yuliandi, I. (2013). South Coastal Community Development: Issues and Challenges. Jurnal Ekonomi Pembangunan, 14 (2). 